\title{
Editorial
}

\section{Understanding Terrorism - The Lure of Terror}

\section{A A Mamun Hussain ${ }^{1}$}

The history of humans is a history of intergroup conflict, whether it be between tribes, kingdoms or nations. In the current national security environment, there is little question that terrorism is among the gravest of threats. Political scientist David Rapoport ${ }^{1}$, identified four waves of modern terrorism, each with its unique characteristics. The Anarchist Wave that started around 1879; the Anticolonial Wave that began around 1920; the New Left Wave that emerged in the 1960s; and the religious wave - the major menace these days that commenced in 1979. Although defining terrorism is a vesting problem, a key-author ${ }^{2}$ has considered terrorism as an act of violence intentionally perpetrated on civilian noncombatants with the goal of furthering some ideological, religious or political objective.

In approaching this task, we are mindful of an incisive conclusion based on more than a quarter century of a personal research on this topic: "Many terrorisms exist, and their character has changed over time and from country to country. The endeavour to find a 'general theory' of terrorism, one overall explanations of its roots, is a futile and misguided enterprise. ... Terrorism has changed in the time and so have the terrorists, their motives, and the cause of terrorism." 3 Psychiatrist Jerrold post ${ }^{4}$ cautions that, ' $\ldots$. Indeed, one should not speak of terrorist psychology in the singular, but rather of terrorist psychologies'.

So, considering the manifold aspect of terrorism, truly fundamental questions about this menace are psychological and socio-psychological. On the individual level of analysis, terrorist behaviour is understood as a form of psychological and/or as reflecting a unique constellation of personality traits.

On the group level of analysis, we often discuss the process of shared reality construction, social influence dynamics in recruitment and indoctrination, and the role of languages in forging terrorism warranting norms. And on the organisational level, we consider issues of training, logistics, and cost effectiveness as they apply to the decisions to launch terrorist activities or desist from their use.

Although the instinct theory, drive theory, social learning theory, and cognitive theory, are often discussed as a theoretical approaches, no single theory has gained ascendance as an explanatory model for all types of violence. So, to the researchers, the quest to understand terrorism by studying terrorist personality traits is likely to be an unproductive area for future investigation and inquiry. ${ }^{5}$ However, current knowledge and biological factors influencing aggression were noted to be lower level of serotonin, lower level of psycho physiological factors and dysfunction of the prefrontal cortex. ${ }^{6}$

As such, considering the facts, there is substantial agreement that the psychology of terrorism cannot be considered apart from political, historical, familial, group dynamics, organic, and even purely accidental, coincidental factors. Researchers have begun to distinguish between reasons for joining, remaining in and leaving terrorist organizations, finding that motivations may be different at each stage, and not even necessarily related to each 
other. There do appear to be some common vulnerabilities and perceptions among those who turn to terrorism - perceived injustice, need for identity and need for belonging - though certainly there are persons who share these perceptions who do not become terrorists. ${ }^{7}$

Surprisingly little research or analysis has been conducted on terrorist recruitment. Three tentative conclusions are as follows: ${ }^{8}$ (i) Terrorists focus their recruitment where sentiments about perceived deprivation are deepest and most pervasive; (ii) Social network and interpersonal relationships provide critical connection for recruitment into terrorist organization, and (iii) effective terrorist recruiters either identify or impart upon the prospect a sense of urgency and imminence to close the deal. John Horgan, as referred in an article of Turi De Angels, ${ }^{9}$ interviewing 60 former terrorists, found that people who are more open to terrorist recruitment and radicalization tend to:

- Feel angry, alienated or disenfranchised

- Believe that their current political involvement does not give them the power to effect real change

- Identify with perceived victims of the social injustice they are fighting

- Feel the need to take action rather than just talking about the problem

- Believe that engaging in violence against the state is not immoral

- Have friends or family sympathetic to the cause

- Believe that joining a movement offers social and psychological rewards such as adventure, camaraderie and a heightened sense of identity

Existing research concludes that terrorist groups vary in their ability to gain media attention through terrorist activity. Some studies have found that terrorists and media outlet have symbiotic relationship, in which both can benefit from coverage of terrorism - other studies reach different conclusions and question the public's appetite for more news about terrorism. ${ }^{10}$
As a concluding remark - we can see that, determining what drives peoples to terrorism is no easy task. Given these complexities the psychology of terrorism is marked more by theory and opinion than by good science, researchers admit. Therefore, it would be more useful to view terrorism in terms of political and group dynamics and processes than individual ones, and that universal psychological principles - such as our subconscious fear of death and our desire for meaning and personal significance - may help to explain some aspects of terrorist actions and our reactions to them.

Again, counterterrorism when is a method of national security, many a mental health professionals round the globe are advocating peaceful-dialogue and de-radicalization programmes; which suggest that assuaging people's fear of cultural annihilation, highlighting our common humanity or demonstrating the discrepancy between the dream and reality of terrorist involvement could keep would-be terrorist form turning to violence, for instance.

\section{References}

1. Rapoport, D. Modern Terrorism: The Four Waves. In A.K. Crown \& J.M. Ludes (Eds), Attacking Terrorism. Washington DC; Georgetown University Press. 2004. p. 46-73.

2. Borum, R. Psychology of Terrorism. Mental Health Law \& Policy Faculty Pub. Paper 571, p. 4. Scholar Commons, University of South Florida, January 2004.

3. Laqueur, W. No End to War: Terrorism in the Twenty-fifth Century. New York: Continuum. 2003.

4. Post, J. The Mind of the Terrorist: Individual and Gr. Psych. of Terrorist beher. Senate Armed Services Committee. November 2001.

5. Marsella, A.J. Terrorism: Reflections on Issues, Concepts, and Directions. Washington DC. American Psychological Assos. 2003. p. 11-48.

6. Bermao, M. et al. Neurotransmitter Correlates of Human Aggression. In Staff, D. et al. (Eds). It Hand Book of Antisocial Behaviour. New York, Wiley. p. 305-313.

7. Fried, R. The Psychology of the Terrorism. Terrorism \& Beyond: An International conference on Terrorism \& Low Level Conflict. Santa Monica; CA: Rand. 1982, p. 119-124. 
8. Crenshaw, M. How Terrorism Ends. Paper Presented at the Annual Meeting of the American Political Science Assoc. Chicago. IL. September 1987.

9. Tori, D.A. Understanding Terrorism, November 2009. Vol. 40, No. 10, p. 1. Am. Psycho. Assoc. New York.
10. James, I.W. Media Attention to Terrorism Attacks: Causes and Consequences. Inst. for Homeland Security Solutions. Research Brief. December 2010, p. 10.

All correspondence to

A. A. Mamun Hussain

Associate Professor Department of Psychiatry Rajshahi Medical College, Rajshahi, Bangladesh 